\title{
Afasia hizkuntzaren antolaketarako erakusleiho
}

Aphasia: a window into the organisation of language

Amaia Munarriz

Euskal Hizkuntza eta Komunikazioa Saila (UPV/EHU)

amaia.munarriz@ehu.eus

DOI: $10.1387 /$ ekaia.14580

Laburpena: Afasiaren azterketak hizkuntzaren antolaketarako ebidentzia enpirikoa eskaintzen du, horregatik da ekarpen garrantzitsua eredu neurolinguistiko eta psikolinguistikoak garatzeko. Lan honetan, afasiologiarako sarrera labur gisa, burmuineko lesioen ikerketak hizkuntzaren eta hizkuntza-osagaien antolaketaz zer erakutsi duen jasotzen da. Horretarako, aurkezten dira, batetik, afasiologiaren historian hizkuntzaren irudikapenaren inguruan izandako ikuspegi nagusiak eta, bestetik, zer-nolako datuak eskaintzen dituen afasiak hizkuntz osagaien antolaketa funtzionalerako eta hizkuntzalaritza teoriarako.

Hitz gakoak: afasia, hizkuntzaren antolaketa, psikolinguistika, neurolinguistika.

Abstract: Research on aphasia provides empirical evidence for the organisation of the language system, and therefore it is a valuable source of data for developing neurolinguistic and psycholinguistic models. In this article, we review what brain lesion studies reveal about the organisation of language and linguistic components, as a brief introduction to aphasiology. To that aim, we introduce the main approaches in the history of aphasia regarding the representation of language in the brain and we present what kind of data aphasia offers for the functional organisation of the linguistic components and for linguistic theory.

Keywords: aphasia, language organisation, psycholinguistics, neurolinguistics.

\section{SARRERA}

Afasia burmuineko lesio baten ondorio den hizkuntza-patologiari deritzo eta hizkuntza-erabilerari dagozkion askotariko arazoak biltzen ditu: 
besteak beste ekoizpen- edota ulermen-arazoak, ahozkoari edota idatzizkoari dagozkionak, hizkuntzak bereizteko ezintasuna elebidunengan edota sintoma desberdinak elebidunen hizkuntzetako bakoitzean [1-3]. Ahozko hizkuntzen hiztunengan bezala, zeinu-hizkuntzen hiztunengan ere hizkuntza-kalteak azaleratzeak [4] erakusten du afasia hizkuntzaren prozesamenduaz arduratzen diren burmuineko eremu/prozesuei eragiten dien patologia dela.

Afasia hartutako kalte zerebralen ondorio da, eta heldu zein haurrengan gerta daiteke, istripu baten ondorioz, antzeko sintomekin. Haurren hizkuntza-arazoez ari garela, komeni da bereiztea bat-bateko burmuineko lesioek eragindakoa den haur-afasia, eta garapen-gaixotasunen ondorio diren hizkuntza-atzerapenak [5]. Afasian, halaber, hizkuntza-arazoekin batera, bestelako gabezia eta ezintasunak azalera daitezke, hala nola arazo motorrak, artikulatorioak edota memoriari dagozkionak, baina afasia hizkuntza(k) erabiltzeko arazoak eragiten dituen patologia da soilik eta ez, ordea, memoria edo pentsamendu mailako nahasmendua [6].

Afasia elebakar zein elebidunak hainbat diziplinatako adituen interesa piztu du, besteak beste neurologo, psikologo, logopeda eta hizkuntzalariena. Elkarrengandik bereizten zailak diren bi galdera nagusiri erantzuten saiatzen dira aditu horiek: batetik, ikuspegi neuroanatomikotik hizkuntza burmuinean nola antolatuta dagoen; bestetik, ikuspegi psikolinguistikotik hizkuntzei eta hizkuntza-osagai bakoitzari zer-nolako egitura eta irudikapena dagokion. Aipatu galderak erantzuteko datuak aurki daitezke era askotako metodo, teknika (jokabidezkoak, neuroirudi bidezkoak, kortexaren estimulazioa) eta ariketa-mota baliatuta eta askotariko parte-hartzaileekin (haur, heldu eta patologiadun elebakar eta elebidunak). Burmuineko lesioen eta haiek eragindako jokabide-ezintasunen azterketa izan da neurolinguistikan ebidentzia enpiriko klasikoa funtzio kognitiboak eta hizkuntzak burmuinean nola antolatu eta irudikatzen diren ulertzeko. Azterketa horietan oinarrituta garatu dira bai hizkuntzaren prozesamenduaren inguruko teoria gehienak $[7,8]$ bai elebidunentzat proposatu diren eredu psikolinguistiko eta neurolinguistiko nagusiak [3, $9,10]$.

Datozen lerroetan afasiak neurolinguistika eta psikolinguistikari egiten dien ekarpenen berri ematen da. Hasteko, hizkuntzaren antolaketa neuroanatomikoaren inguruan afasiologiaren historian izandako ikuspegi nagusiak jasotzen dira, hain zuzen, ikuspegi lokalizazionista eta holistikoa. Bigarrenik, neuropsikologia kognitiboan burmuineko lesioek zer-nolako datuak ekartzen dituzten adierazi ondotik, afasiak hizkuntzaren osagaien antolaketa funtzionalerako eta hizkuntzalaritza teoriarako eskaintzen dituen ebidentziak aurkezten dira. 
Afasia hizkuntzaren antolaketarako erakusleiho

\section{HIZKUNTZAREN ANTOLAKETA AFASIOLOGIAN: IKUSPEGI HISTORIKOA}

Afasiologiaren historian hizkuntzek burmuinean duten antolaketari buruzko bi korronte kontrajarri dira aipagai: a) ikuspegi lokalizazionistaren arabera, prozesu kognitiboak funtzio jakinetarako espezializatutako burmuineko gune zehatzetan kokatzen dira, eta b) ikuspegi ez-lokalizazionista edo holistikoari jarraituz, burmuineko eremuen artean askotariko loturak daude, eta hizkuntza prozesatzeko eremuak beste funtzio batzuetarako ere erabiltzen diren hainbat gunez osatuta daude.

\subsection{Ikuspegi lokalizazionista}

XIX. mendean Dax (1770-1837), Broca (1824-1880), Wernicke (18481905) bezalako neurologoek afasia izandakoen burmuinen azterketatik abiatuta, korrelazioak aurkitu zituzten lesioen kokaguneen eta haien ondorio ziren hizkuntza-ezintasunen artean, eta hizkuntza-gaitasuna ezker hemisferioan lateralizatuta zegoela ondorioztatu zuten. Hain zuzen, Broca neurologo frantsesak, «tan» silaba soilik ekoizteko gai zen Leborgne izeneko paziente baten burmuinaren autopsia aztertzean matxura hirugarren zirkunboluzio frontaleko atzeko aldeko gainazalean zegoela aurkitu ondoren, hizkuntza artikulatua ezker hemisferioko lobulu frontalean kokatzen zela adierazi zuen 1861ean. 1876an Wernicke neurologo alemanak ulermen-arazoak zituen gaixo baten burmuina aztertu zuen. Goiko aldeko zirkunboluzio tenporalaren atzealdean aurkitu zuen lesioa, eta ondorioztatu zuen hitzen memoria auditiboa eremu horretan gordetzen zela. Gainera, Wernickek Brocaren eta Wernickeren eremu deiturikoak loturik zeudela proposatu zuen. Neurologo horien lanen ondorioz, Brocaren «adierazpen» afasiaren ( expressive» aphasia) eta Wernickeren afasia «harkorra»ren («receptive» aphasia) arteko bereizketa ezarri zen. Era berean, bi gune horien arteko loturaren matxurak eragindako kondukzio afasia aurreikusi zuen Wernickek. Lan horietan oinarrituta proposatu zuen Lichtheim-ek 1885ean Wernicke-Lichtheim eskema deritzon hizkuntzaren eredu neurologiko klasikoa. Eredu horren arabera anatomikoki bereiziak diren baina elkarren arteko loturak dituzten honako gune hauek daude (1. irudia): entzumenerako edo hizkuntzaren ulermenerako Wernickeren eremua, hizkuntzaren artikulaziorako (eta antolaketa gramatikalerako) Brocaren eremua, eta biak lotzen dituen arkudun faszikulua (arcuate fasciculus) [11, 12].

Eredu horri jarraiki, Geschwind-ek Xx. mendean proposatu zuen oraindik klinikan oso ohikoa den lesio-kokagunean oinarritutako afasia-moten sailkapena. Gainera, afasia-motak identifikatzeko baliatu ohi den Boston bateria ere garatu zuen bere lankideekin batera. Hein handi batean Geschwindi zor zaio oraindik ere erabiltzen den «Bostongo eskola»n garatutako afasietarako taxonomia orokorra eta afasiak sailkatzeko jariota- 


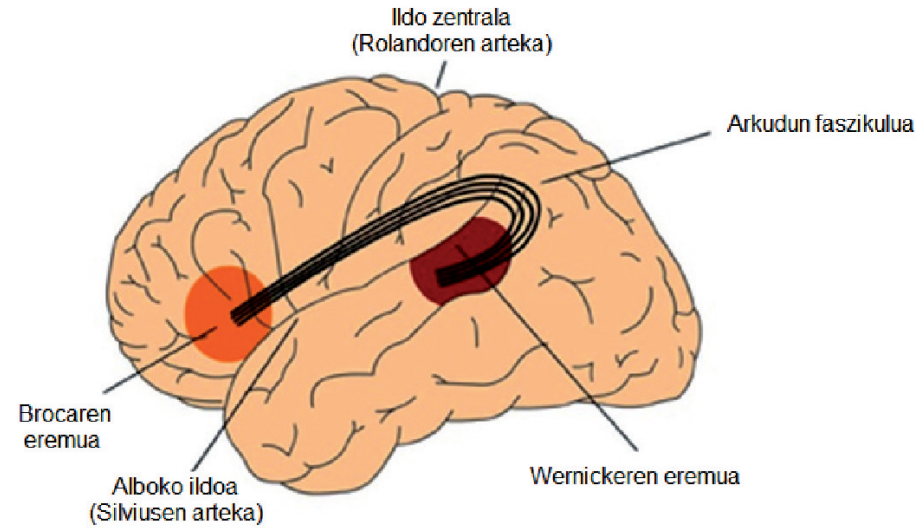

1. irudia. Wernicke-Lichtheim-Geschwind eredu klasikoaren irudikapena ([13] lanetik moldatua).

sunean oinarritutako bereizketa (afasia jariakor vs. ez-jariakor). Afasiaren sindrome-tipologia klasikoan 1. taulan ageri direnak bereizten dira $[6,11$, 14]. Oro har, afasia-mota horietako bakoitza burmuineko eremu jakin baten lesioarekin lotzen da (ikus 2. irudia).

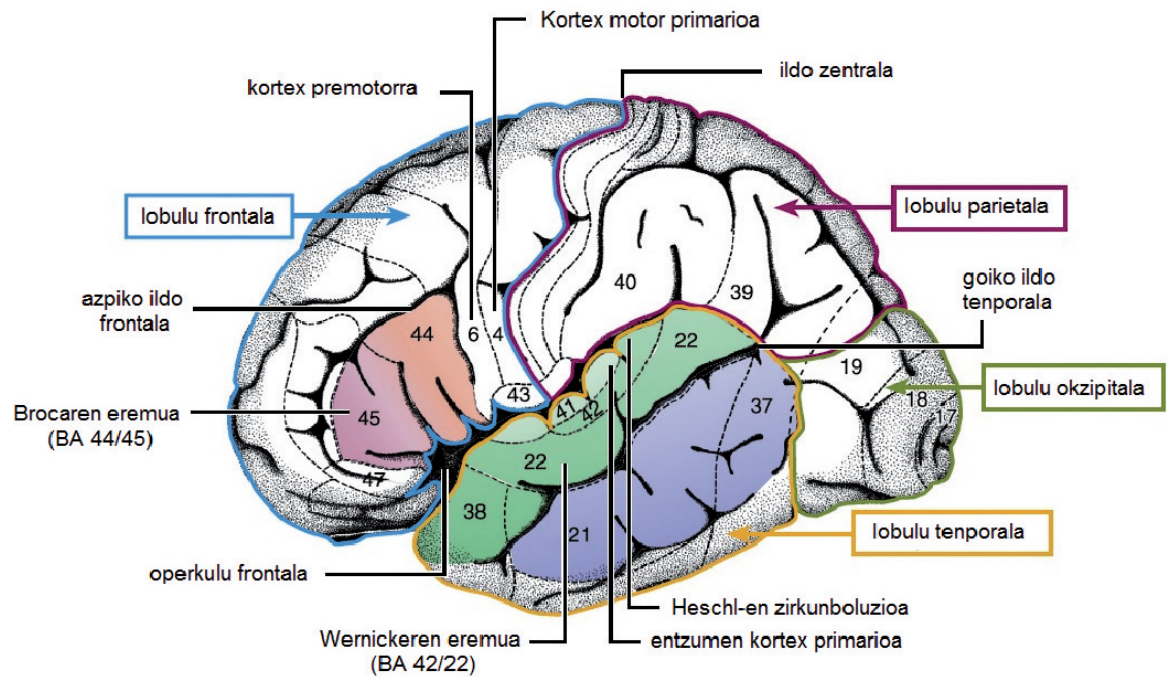

2. irudia. Ezker hemisferioaren zehaztasun anatomiko eta zitoarkitektonikoak ${ }^{1}$ ([15] lanetik moldatua).

1 Kortexeko neurona moten dentsitatean oinarrituta burmuineko eremuen sareari buruzko informazioa lor daiteke, eta hain zuzen horrela lortu zuen Broadmann-ek giza kortexaren lehen deskribapen zitoarkitektonikoa [15]. 
Afasia hizkuntzaren antolaketarako erakusleiho

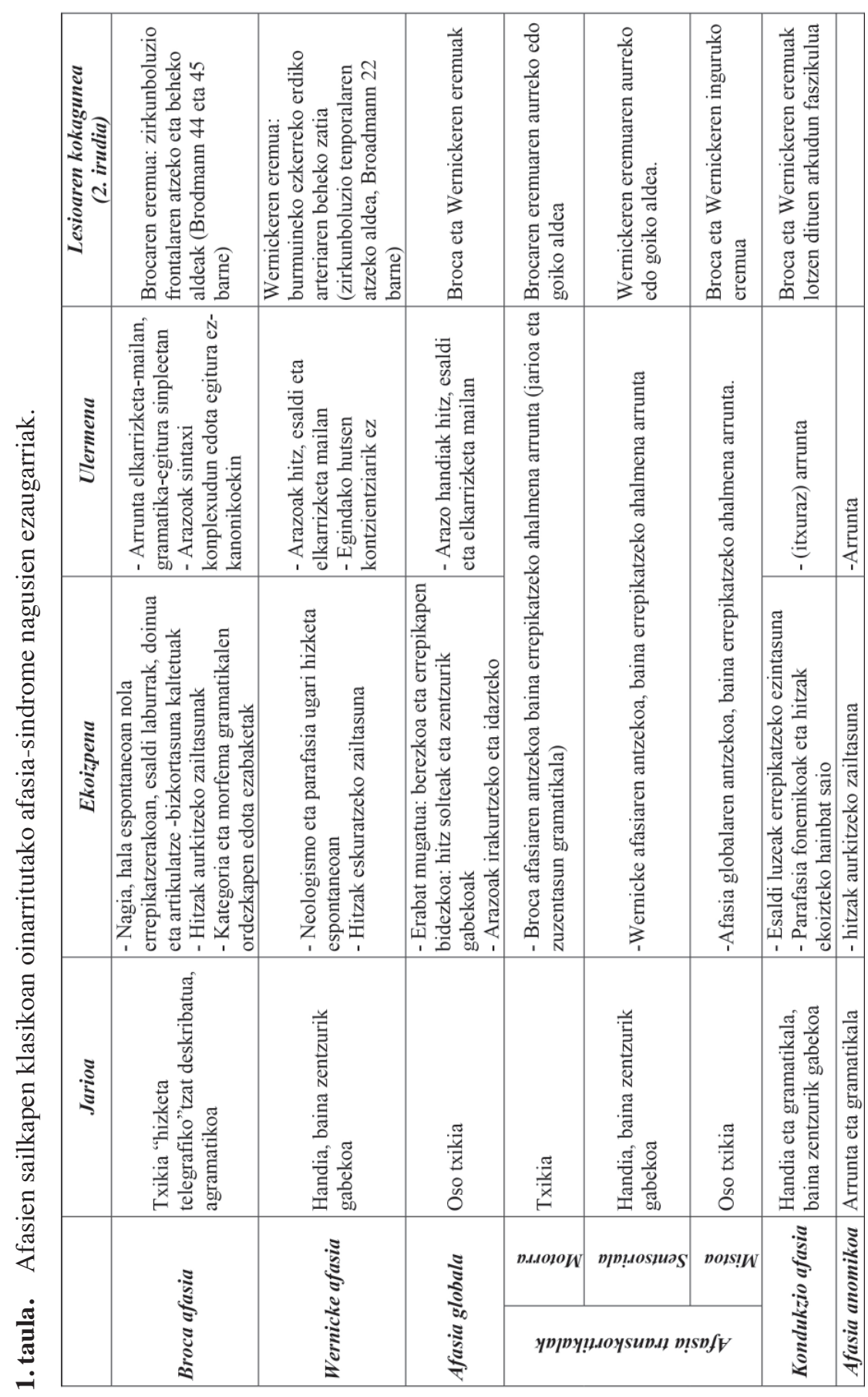

EKAIA, 30 (2016) 


\subsection{Ikuspegi holistikoa}

Eredu honek ehun bat urtez iraun bazuen ere, 1960-1970etik aurrera ikuspegi aldaketa gertatu zen afasiaren azterketan hainbat psikolinguista eta hizkuntzalariren eskutik, eredu klasikoak zuen hizkuntzaren irudi sinplifikatuari (ekoizpena vs. ulermena) aurre egin nahiaren ondorioz. Gramatika sortzailean oinarrituta azaldu nahi zituzten garai hartako afasiologo zenbaitek [16-18] afasiako hizkuntza-urradurak, Chomskyk eta proposaturiko giza hizkuntz gaitasunaren analisi modularraren baitan. Hizkuntzalaritza eta psikolinguistikaren tresna teoriko eta esperimentalez baliatuz, burmuineko lesioen formak eta hizkuntza-sintoma zehatzak erkatu zituzten gramatika jaiotzetikoa den «burmuineko organo» autonomoa delako proposamenaren aldeko ebidentzia bilatu nahian [19]. Hein handi batean ikuspegi lokalizazionistaren eskema mantendu egin zen, analisi unitateak aldatu arren; hizkuntza-azpisistemak eta hizkuntza-moduluak eremu jakinetan kokatzen zirela proposatu zuten. Broca afasia gramatikaren (hain zuzen ekoizpen eta ulermen sintaktikoa) kalte espezifiko gisa berrinterpretatu zen, afasia mota horretan semantika lexikal eta proposizionala ukitu gabe zegoela ikusita, eta Wernicke afasia, berriz, gramatika osorik mantentzen zuen semantikaren kalte espezifiko gisa. Garai hartan onartzen zen gramatika eta semantikaren artean disoziazio argia zegoela, eta bi alor horiei dagozkien burmuin-sistema zehatzen arteko lotura gardena zela: Brocaren eremua prozesamendu sintaktikorako, eta Wernickeren eremua prozesamendu lexiko-semantikorako $[19,20]$.

Hurbilketa lokalizazionista entzute handikoa izan zen XIX. mendean, baina ikuspegi hori zalantzan jarri zuten gerora holistikoa esan zaion ikuspegiaren defendatzaileek, horien artean Jackson-ek, Freud-ek eta Marie-k, besteak beste $[1,12]$. Holistek lokalizazionisten hizkuntza-eremuak gero eta gune murritzagoetara mugatu behar horren kontrako joera zuten, eta hizkuntza beste gaitasun kognitiboekin (memoria, arreta, etab.) erlazionatzen zen modua bereziki nabarmentzen zuten, burmuineko eremuen artean askotariko loturak zeudelakoan. Jackson neurologo ingelesaren ustez, lesio batek funtzio batean eragina izateak ez du esan nahi funtzio horren ardura burmuineko gune jakin horrek bakarrik duenik, izan ere matxuratutako guneak funtzio orokorragoa izan bailezake burmuinean eta funtzio horretaz arduratzen diren eremuak ere gehiago izan bailitezke. Ildo beretik, Freudek 1891an burmuin-antolaketarako eredu dinamiko eta plastikoago bat proposatu zuen egungo burmuin-sareen hurbilketatik gertu [12, 19].

XX. mende amaieratik aurrera ere hizkuntza-lokalizazioaren eredu tradizionala kolokan jarri izan da. Teknologia garapenari esker, gaur egungo ikerketa neuropsikolinguistikoek aukera ematen dute afasikoak zehatzago aztertzeko, eta hala afasia mota nagusiak lesio-guneekin zer-nolako loturak dituzten ikusteko aukera dago besteak beste estimulazio kortikala edo neuroirudi teknikei esker $[12,21]$. Neuroirudi tekniken bidez egindako 
Afasia hizkuntzaren antolaketarako erakusleiho

ikerketek erakutsi dute sindromeetan oinarritutako eredu tradizionala balio gabeko suertatzen dela. Batetik, nekez erlaziona daitezke afasia sindromeak (1. taula) eta lesio-guneak sindrome berean sailkaturiko afasikoek ez dutelako ezintasun berdina izaten, sindrome bera dutenen lesioa ez delako afasiko guztiengan eremu batean kokatzen eta eremu jakin bat matxuratuta dutenei ez baitzaie sindrome berdina azaleratzen [11, 14]. Bat-etortze ezaren erakusgarri dira Dronkers-ek [22] bere kideekin batera egindako ikerketetako datuak: Brocaren eremua matxuratuta dutenen \%50-60ak bakarrik du Broca afasiaren sintomatologia, eta Broca afasiaren diagnostikoa dutenen \%85ak soilik du Brocaren eremua kaltetuta. Wernicke afasiaren sintomak dituztenen \%65ak bakarrik du lesioa Wernickeren eremuan eta Wernickeren eremua hondatuta dutenen \%30ak bakarrik ditu Wernicke afasiaren sintomak. Horregatik, Broca afasia ez da teorikoki koherentea den sindrome bat, eta Broca afasiaren ezaugarri diren hizketa agramatikoa, artikulazio atzendua, aditz ekoizpena eta ulermen ezintasuna ez dira ezintasun funtzional bakarraren ondorio. Hillis-ek [14] sindrome baskular deritze hurbileko burmuin-eremuen menpe dauden hizketa eta hizkuntza-funtzio multzo baten matxuraren ondorio diren horiei. Hortaz, afasia sindromeak edo hizkuntzaren osagaiak (sintaxia vs. semantika) hizkuntza-nahasmenduaren ezaugarri nagusiak laburbiltzeko baliagarri diren etiketa modukoak dira, baina lausoak dira hizkuntza prozesatzeko mekanismoak aztertzeko eta hizkuntza-ezintasunen oinarrian dagoen lesioa anatomikoki eta funtzionalki kokatzeko $[1,11,12,14]$.

Bestetik, Pulvermüller-ek [12] dioenez, EEG eta MEG edo PET eta fMRI bezalako neuroirudi teknika berriek erakutsi dute: a) eremu klasikoek bestelako funtzioak ere badituztela, adibidez Brocaren eremua oharmenerako ere baliatzen dela edota Wernickeren eremua ekoizpenerako ere garrantzizkoa dela eta b) hizkuntza prozesatzean eremu horiez gain bestelako gune kortikal eta subkortikalak ere aktibatzen direla, hala nola zerebeloa, ganglio basala eta talamoa, eta baita eskuin hemisferioko eremuak ere.

Hurbilketa lokalizazionista eta holistikoaren arteko eztabaidak bizirik dirau oraindik, baina egungo ikerketak bi mutur horietatik aldendu egin dira eta proposamen zehatz eta sofistikatuagoak eskaintzen dituzte. Eredu lokalizazionistaren oinarriak antzeman daitezke oraindik eragin handikoak diren zenbait eredu eta teoria neuropsikolinguistikotan, hala nola Grodzinskyren [20] Aztarna Ezabaketaren Hipotesia (Trace Deletion Hypothesis, TDH) edo Ullmanen Eredu deklaratibo-prozeduralean [10], eta baita elebidunekin buruturiko neuroirudi [23] eta estimulazio kortikal bidezko [24] ikerketa enpirikoetan ere.

Beste lan batzuk hurbilketa ez-lokalizazionistatik gertuago daude oro har, eta sindrome desberdina dutenen sintomen arteko desberdintasunik ez dagoela diote $[17,25]$ edota hizkuntza-osagai eta prozesuen arteko askotariko loturak dituzten ereduak eta simulazioak proposatzen dituzte [7]. Mu- 
turreko ikuspegi lokalizazionista baztertzeko aipaturiko argudioez gain, hizkuntza-osagaien araberako burmuinaren antolaketa zalantzan jartzeko honako argudio hauek aipatzen dituzte Dick-ek eta [19]: a) disoziazio bikoitz argirik eza prozesamendu gramatikal eta lexikoaren artean; b) agramatikoek hizkuntzaren gramatikaren ezaugarri batzuk mantentzen dituzte, hau da ez dute osagai morfosintaktikoari dagokion modulua erabat urratuta; c) morfosintaxi mailako urraketak ez dira afasia mota bakarrean azaleratzen, eta ez dira burmuin-eremu jakin baten lesioaren ondorio; d) prozesatzeko baldintza desegokietan, antzerako ulermen-zailtasuna dute patologiadunek eta patologiarik gabekoek, eta horrek iradokitzen du ezintasunek hizkuntzaz kanpoko eragilea dutela.

\section{HIZKUNTZEN ANTOLAKETA FUNTZIONALA}

70eko hamarkadako neuropsikologia modernoaren hastapena mugarri izan da lesioen azterketan. Patologiek (tartean afasiak) aukera ematen dute sistema kognitiboaren arkitektura konplexua ezagutzeko bertako prozesatze-unitate, irudikapen eta loturetarako ebidentzia eskaintzen baitute [1, 14, 26, 27]. Honako hauek dira neuropsikologia kognitiboaren 4 hatsarre nagusiak [26]:

- Modularitate funtzionala: Fodor-i [28] jarraituz, neuropsikologian modulutzat hartzen da helburu jakin batzuetarako informazio zehatz bat prozesatzeaz arduratzen den mekanismoa. Ezagutza sistema modulutan banatuta dago, eta modulu bakoitzak zeregin zehatz bat du.

- Modularitate ANATOMIKOA: neurologoek azterturiko gune kortikalen eta psikologoek aztertutako modulu kognitiboen artean korrespondentzia argiak aurkitu dira. Alabaina, hizkuntza-sisteman oraindik ez da korrespondentzia argirik aurkitu $[14,27]^{2}$.

- BERDINTASUNA: pertsona guztiek egitura funtzional berbera dute.

- Kengarritasuna (subtractivity): sistema kognitibo urratua sistema kognitibo osoa bezalakoa da, baina modulu edo lotura batzuk hondatuta ditu. Alegia, urradurak ez du modulu edo lotura berririk eragiten, nahiz eta zailtasunak orekatzeko estrategia berriak baliatzea eragin dezakeen.

Neuropsikologia modernoan nahasmendu kognitiboak ikertzearen helburua hauxe da: hizkuntza bezalako sistema kognitiboen eredu zehatz bat

\footnotetext{
2 Neuropsikologia modernoan modularitatearen ikuspegia onartuta ere, ez da zalantzan jartzen hizkuntzak beste funtzio kognitiboekin duen lotura. Hillisek [14] dioenez, irudikapen kognitiboak burmuineko eremu askotan banatuta dauden tasunek osatzen dituzte eta tasun guztien aldibereko aktibazioak «irudikapena» eratzen du.
} 
Afasia hizkuntzaren antolaketarako erakusleiho

formulatzea, eta sistema hori hondatzen denean, eredu (simulazio) horrek nahasmendua dutenen sistemak bezala funtzionatzen duela erakustea. Burmuineko lesioa dutenek funtzio kognitiboen antolaketa eta egituraketarako hipotesi eta teoriak proposatzeko ebidentzia nagusia eskaintzen dute, disoziazio bikoitzei esker. Disoziazio bikoitza deritzo gaixo bik, gutxienez, funtzio kognitibo biri dagokienez, kontrako jokabidea dutenekoari, hain zuzen, batek A osagaia dauka eraginda eta B osorik, eta besteak, alderantziz, B eraginda eta A osorik. Disoziazio bikoitzek aditzera ematen dute osagaiak modulu kognitibo bereiziak direla [26, 27, 29]. Esate batera, hitzak eskuratzeko zailtasunei dagokienez, afasiko batzuek aditzak eskuratzeko arazoak dituzte (izenak eskuratzeko arazorik izan gabe), eta beste batzuek, berriz, ez dute arazorik aditzak eskuratzeko, bai, ordea, izenak eskuratzeko. Disoziazio bikoitz horrek erakusten du bi kategoria horiek burmuineko prozesu/egitura desberdinen ondorio direla [30].

Afasikoen hizkuntz ezintasunen deskribapen zehatzak euskarri sendoa izan dira hizkuntza-ekoizpen eta -ulermen ereduak garatzeko. Burmuineko lesioen ondorioz gerta daiteke hizkuntza prozesatzeko ahalmena nolabait urritzea, dela osagai jakin batek ohi bezala funtzionatzeari uzten diolako, dela osagaien koordinazioan arazoak suertatzen direlako. Afasian hizkuntzaren urratzeak ez die beti osagai guztiei berdin eragiten (prozesamendu sintaktikoa, hitzak berreskuratzea, hotsen ordenamendua etab.). Urradura zehatzek hizkuntza prozesatzean gertatzen diren urratsetan sakontzea eta sistemaren eragiketa normalak inferitzea ahalbidetzen dute hizkuntzen eta hizkuntza-osagaien disoziazioetan oinarrituz [1, 3, 7, $8,26,31]$. Horren adibide da hizkuntza-nahasmenduak dituztenen disoziazio bikoitzen ebidentzietan oinarrituta garatu den eredu psikolinguistiko orokorra (3. irudia).

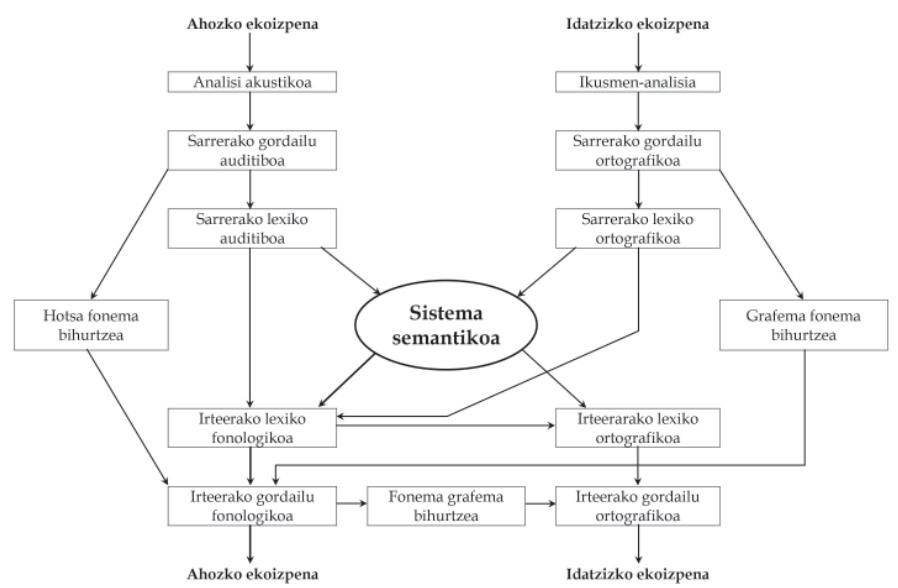

3. irudia. Hitzak prozesatzean eragiten duten prozesuak ([29] lanetik moldatua). 
Halaber, afasikoen jokabidea hizkuntzalaritza teorikoan egindako proposamen eta hipotesiak enpirikoki egiaztatu edo deuseztatzeko baliagarri gertatzen da, afasiako datuak proposamen horietarako baliagarritasun test modukoak izanik, hizkuntza-unitateen antolaketari eta irudikapenari buruzko hipotesiak garatzea ahalbidetu baitute $[17,27,29,30]$. Esate batera, osagai fonologikoari dagokionez, afasikoen hutsetan islatzen da teoria fonologikoko tasun bereizgarriei dagokien markatutasuna $[17,32]$ eta bokal eta kontsonanteen bereizketa [33]. Beste hainbat kontzeptu gramatikaletarako ebidentzia ere eskaini dute afasikoen ezintasun eta disoziazioek, hala nola, izen eta aditz kategoria gramatikalen bereizketarakoa [30], inflexio eta eratorpen morfologiaren bereizketarakoa [34], egitura sintaktikoen hierarkia eta proposamenetarakoa [35], eratorpen sintaktikoko eragiketa jakinetarakoa [20] eta kate sintaktiko motetarakoa [36].

Azkenik, aipatzekoa da afasiologian argitzeke dauden eztabaidetarako aztertu gabeko edo gutxi aztertutako hizkuntzetako hiztun afasikoen datuak ekartzeko beharra [37]. Hizkuntza-nahasmenduaren sintomak ez dira hizkuntza guztietan modu berean azaleratzen, horregatik, patologiaren oinarrian dagoen ezintasuna mugatzeko eta zehazteko aukera paregabea eskaintzen dute ezaugarri tipologiko desberdinak dituzten hizkuntzen hiztun afasikoek [37-39]. Ildo horretan, ez dago zalantzarik euskal afasikoekin burututako ikerketa enpirikoek [40-46] ekarpen garrantzizkoa egiten diotela neuropsikolinguistikari.

\section{ONDORIOAK}

Afasiaren azterketak hizkuntzen antolaketa neuroanatomiko eta neurokognitiborako zer-nolako datuak eskaintzen dituen aurkeztea izan da artikulu honen helburua, afasiologiarako sarrera gisa. Garapen historikoari heldu diogu lehenik, afasiaren azterketan hizkuntzen antolaketari dagokionez dauden ikuspegi lokalizazionista eta holistikoa aurkeztu ditugu. Ondoren, afasiak hizkuntzaren eta hizkuntza-osagaien antolaketa funtzionalaz zer-nolako ebidentziak eskaintzen dituen erakutsi dugu, bai neuropsikologia kognitiboari dagokionez, baita hizkuntzalaritza teorikoari dagokionez ere. Hala, afasikoen azterketek neuropsikolinguistikari egiten dioten ekarpena handia dela erakutsi dugu.

\section{ESKER ONAK}

Lan honek Eusko Jaurlaritza (IT-676-13), UPV/EHU (UFI11/6) eta Espainiako MINECO eta FEDER (FFI2012-37884-C03-02 eta FFI201568589-C2-1-P (MINECO/FEDER)) ikerketa proiektuen diru-laguntza izan 
Afasia hizkuntzaren antolaketarako erakusleiho

du. Halaber, eskerrak eman nahi dizkiet Maria José Ezeizabarrenari bere ohar eta iruzkinengatik eta testu hau hobetzen lagundu duten orraztaileei.

\section{BIBLIOGRAFIA}

[1] GOODGLASS, H. 1993. Understanding aphasia. Academic Press, San Diego.

[2] CAPLAN, D. 1992. Introducción a la Neurolingüística y al estudio de los trastornos del lenguaje. Visor distribuciones, Madrid.

[3] PARADIS, M. 2004. A neurolinguistic theory of bilingualism. John Benjamins, Amsterdam/Philadelphia.

[4] BELLUGI, U., POIZNER, H. eta KLIMA, E.S. 1983. «Brain organization for language: clues from sign aphasia». Human Neurobiology, 2, 155-70.

[5] ALAJOUANINE, T.H. eta LHERMITTE, F. 1965. «Acquired aphasia in children». Brain, 88, 653-62.

[6] HELM-ESTABROOKS, N. eta ALBERT, M.L. 2005. Manual de la afasia y de terapia de la afasia. Editorial Médica Panamericana, Buenos Aires.

[7] DELL, G.S., SCHWARTZ, M.F., MARTIN, N., SAFFRAN, E.M. eta GAGNON, D.A. 1997. «Lexical access in aphasic and nonaphasic speakers». Psychological Review, 104, 801-38.

[8] LEVELT, W.J.M., ROELOFS, A. eta MEYER, A.S. 1999. «A theory of lexical access in speech production». Behavioral and Brain Sciences, 22, 1-75.

[9] GREEN, D.W. 2005. «The neurocognition of recovery patterns in bilingual aphasics». In KROLL, J.F. eta DE GROOT, A.M.B., eds. Handbook of bilingualism: psycholinguistic approaches. 516-30, Oxford University Press, New York.

[10] ULLMAN, M.T. 2004. «Contributions of memory circuits to language: the declarative/procedural model». Cognition, 92, 231-70.

[11] DRONKERS, N.F., REDFERN, B.B. eta KNIGHT, R.T. 2000. «The neural architecture of language disorders». In GAZZANIGA, M.S., ed. The new cognitive neurosciences. 949-60, MIT Press, Cambridge, MA.

[12] PULVERMÜLLER, F. 2002. «From classic aphasia research to modern neuroimaging». In PULVERMÜLLER, F., ed. The neuroscience of language. 33-49, Cambridge University Press, Cambridge, U.K.

[13] HAGOORT, P. 2013. «MUC (Memory, Unification, Control) and beyond». Frontiers in Psychology, 4, 1-13.

[14] HILLIS, A.E. 2007. «Aphasia: progress in the last quarter of a century». Neurology, 69, 200-13.

[15] FRIEDERICI, A.D. 2011. «The brain basis of language processing: From structure to function». Physiological Reviews, 91, 1357-92.

[16] CARAMAZZA, A. eta ZURIF, E.B. 1976. «Dissociation of algorithmic and heuristic processes in language comprehension: Evidence from aphasia». Brain and Language, 3, 572-82. 
[17] BLUMSTEIN, S.E. 1973. A phonological investigation of aphasic speech. Mouton, The Hague.

[18] GRODZINSKY, Y. 1984. «The syntactic characterization of agrammatism». Cognition, 16, 99-120.

[19] DICK, F., BATES, E., WULFECK, B., UTMAN, J.A., DRONKERS, N. eta GERNSBACHER, M.A. 2001. «Language deficits, localization, and grammar: Evidence for a distributive model of language breakdown in aphasic patients and neurologically intact individuals». Psychological Review, 108, 759-88.

[20] GRODZINSKY, Y. 2000. «The neurology of syntax: Language use without Broca's area». Behavioral and Brain Sciences, 23, 1-71.

[21] ABUTALEBI, J., CAPPA, S.F. eta PERANI, D. 2005. «What can functional neuroimaging tell us about the bilingual brain». In KROLL, J.F. eta DE GROOT, A.M.B., eds. Handbook of bilingualism: Psycholinguistic approaches. 497-515, Oxford University Press, New York.

[22] DRONKERS, N.F. 2000. «The pursuit of brain-language relationships». Brain and Language, 71, 59-61.

[23] KIM, K.H.S., RELKIN, N.R., LEE, K.-M. eta HIRSCH, J. 1997. «Distinct cortical areas associated with native and second languages». Nature, 388, 171-4.

[24] OJEMANN, G.A. eta WHITAKER, H.A. 1978. «The bilingual brain». Archives of Neurology, 35, 409-12.

[25] CAPLAN, D., WATERS, G., DEDE, G., MICHAUD, J. eta REDDY, A. 2007. «A study of syntactic processing in aphasia I: Behavioral (psycholinguistic) aspects». Brain and Language, 101, 103-50.

[26] COLTHEART, M. 2001. «Assumptions and methods in cognitive neuropsychology». In RAPP, B., ed. The handbook of Cognitive Neuropsychology: what deficits reveal about the human mind. 3-21, Psychology Press, Philadelphia.

[27] SELNES, O.A. 2001. «A historical overview of contributions from the study of deficits». In RAPP, B., ed. The handbook of Cognitive Neuropsychology: what deficits reveal about the human mind. 23-41, Psychology Press, Philadelphia.

[28] FODOR, J.A. 1983. The Modularity of Mind. MIT Press, Cambridge, MA.

[29] CUETOS, F. 1998. Evaluación y rehabilitación de las Afasias. Aproximación cognitiva. Editorial Médica Panamericana, Madrid.

[30] SHAPIRO, K. eta CARAMAZZA, A. 2003. «The representation of grammatical categories in the brain». Trends in Cognitive Science, 7, 201-6.

[31] LAINE, M. eta MARTIN, N. 2006. Anomia: Theoretical and Clinical Aspects. Psychology Press, Hove.

[32] GOLDRICK, M. eta RAPP, B. 2007. «Lexical and post-lexical phonological representations in spoken production». Cognition, 102, 219-60.

[33] CARAMAZZA, A., CHIALANT, D., CAPASSO, R. eta MICELI, G. 2000. «Separable processing of consonants and vowels». Nature, 403, 428-30.

[34] MICELI, G. eta CARAMAZZA, A. 1988. «Dissociation of inflectional and derivational morphology». Brain and Language, 35, 24-65. 
[35] FRIEDMANN, N. eta GRODZINSKY, Y. 1997. «Tense and Agreement in Agrammatic Production: Pruning the Syntactic Tree». Brain and Language, 56, 397-425.

[36] HICKOK, G. eta AVRUTIN, S. 1996. «Comprehension of Wh-questions in two Broca's aphasics». Brain and Language, 52, 314-27.

[37] BEVERIDGE, M.E.L. eta BAK, T.H. 2011. «The languages of aphasia research: Bias and diversity». Aphasiology, 25, 1451-68.

[38] MENN, L. eta OBLER, L.K. 1990. Agrammatic aphasia: a cross-language narrative sourcebook. John Benjamins, Philadelphia.

[39] PARADIS, M. 2001. «The need for awareness of aphasia symptoms in different languages». Journal of Neurolinguistics, 14, 85-91.

[40] ERRIONDO, L. 1995. Afasiko elebidunen hizkuntz trebetasunen azterketa. UPV/EHU, Bilbo.

[41] LAKA, I. eta ERRIONDO, L. 2001. «Aphasia manifestations in Basque». Journal of Neurolinguistics, 14, 133-57.

[42] ADROVER-ROIG, D., GALPARSORO-IZAGIRRE, N., MARCOTTE, K., FERRÉ, P., WILSON, M.A. eta ANSALDO, A.I. 2011. «Impaired L1 and executive control after left basal ganglia damage in a bilingual Basque-Spanish person with aphasia». Clinical Linguistics and Phonetics, 25, 480-98.

[43] POURQUIÉ, M. 2013. «Verb processing in Basque and French agrammatic aphasia: A «post-lexical access» deficit». Aphasiology, 27, 1472-510.

[44] POURQUIÉ, M. 2011. Approche neuropsycholinguistique du traitement des verbes dans l'aphasie agrammatique. Etude translinguistique de cas: basque et français. Toulouse: Université Toulouse II-Le Mirail.

[45] MUNARRIZ, A. 2015. Hizkuntzen antolaketa burmuin elebidunean: gaztelania-euskara elebidun afasiko baten kasu-azterketa. UPV/EHU.

[46] MUNARRIZ, A., EZEIZABARRENA, M.J. eta GUTIERREZ-MANGADO, M.J. 2016. «Differential and selective morpho-syntactic impairment in Spanish-Basque bilingual aphasia». Bilingualism, Language and Cognition, 19, 810-33. 